\title{
A SEISMOTECTONIC MAP OF EASTERN SIBERIA
}

\author{
V. S. Imaev1, L. P. Imaeva1, O. P. Smekalin'1, B. M. Koz'min², \\ N. N. Grib ${ }^{3}$, A. V. Chipizubov ${ }^{1}$ \\ ${ }^{1}$ Institute of the Earth's Crust, Siberian Branch of RAS, Irkutsk, Russia \\ ${ }^{2}$ Institute of Diamond and Precious Metals Geology, Siberian Branch of RAS, Yakutsk, Russia \\ ${ }^{3}$ Technical Institute (branch) of M.K. Ammosov North-Eastern Federal University, Neryungri, Russia
}

\begin{abstract}
The paper reviews goals and objectives, stages and the content of seismotectonic studies conducted in Eastern Siberia. Such studies are based on a comprehensive analysis of geological and geophysical data and provide for establishing whether the local earthquakes are of tectonic origin and revealing their relationships with recent geodynamic processes in the area under study. Seismic hazard assessment and evaluation of tectonic processes are the two major, closely interrelated aspects of seismotectonic studies. The latter are generally conducted in combination with seismic studies prior to the stage of detailed seismic zonation (DSZ) which is followed by seismic micro-zonation (SMZ). In three stages of seismotectonic studies, we analyse specific geological structures, reveal the regional dynamics of seismotectonic processes, clarify details of potential seismic hazard locations and identify sites of the potential instantaneous deformation of the crust which may take place due to active faulting. Based on results of the long-term studies conducted by the authors, a seismotectonic map of Eastern Siberia is compiled. The paper briefly reviews the methods of mapping and refers to data on active faults and neotectonic structures revealed in the area under study, which are closely related to regional earthquake sources.
\end{abstract}

Key words: seismotectonic studies, seismic hazard, active faults, geological and geomorphological methods, trenching, seismic source zones, seismic belts and their segments, seismotectonic map of Eastern Siberia.

\section{Recommended by S.I. Sherman}

For citation: Imaev V.S., Imaeva L.P., Smekalin O.P., Koz'min B.M., Grib N.N., Chipizubov A.V. 2015. A seismotectonic map of Eastern Siberia. Geodynamics \& Tectonophysics 6 (3), 275-287. doi:10.5800/GT-2015-6-30182.

\section{КАРТА СЕЙСМОТЕКТОНИКИ ВОСТОЧНОЙ СИБИРИ}

\author{
В. С. Имаев¹, Л. П. Имаева', О. П. Смекалин¹, Б. М. Козьмин², \\ Н. Н. Гриб ${ }^{3}$, А. В. Чипизубов 1
}

${ }^{1}$ Институт земной коры СО РАН, Иркутск, Россия

${ }^{2}$ Институт геологии алмаза и благородных металлов СО РАН, Якутск, Россия

3 Технический институт (филиал) Северо-Восточного федерального университета им. М.К. Аммосова, Нерюнгри, Россия

Аннотация: В статье рассматриваются задачи, стадийность проведения и содержание сейсмотектонических исследований как отдельного вида анализа комплексных геолого-геофизических материалов, используемых для установления тектонической природы проявлений местных землетрясений и их связи с современными геодинамическими процессами, протекающими на исследуемой территории. В задачи сейсмотектонических исследований входят два тесно взаимосвязанных направления: оценка опасности сейсмических явлений и оценка 
тектонических процессов. Сейсмотектонические исследования, совместно с сейсмологическими, всегда предваряют стадию детального сейсмического районирования (ДСР) и в последующем - сейсмического микрорайонирования (СМР). Сами сейсмотектонические исследования проводятся в три этапа и позволяют на региональном уровне изучения конкретных геологических структур определить геодинамику сейсмотектонических процессов, провести детальную локализацию сейсмической опасности и выявить места возможного проявления мгновенных деформаций земной поверхности, связанных с активными разломами. Результаты многолетних авторских исследований обобщены в карте сейсмотектоники Восточной Сибири, для которой дается краткое описание принципов и методов ее построения, приводятся наглядные примеры выделенных активных разломов и неотектонических структур, тесно связанных с региональными эпицентрами землетрясений.

Ключевые слова: сейсмотектонические исследования, сейсмическая опасность, активные разломы, геологогеоморфологические методы, тренчинг, зоны В03, сейсмические пояса и их сегменты, карта сейсмотектоники Восточной Сибири.

\section{1. ВВЕДЕНИЕ}

При проведении многолетних работ по установлению вероятных связей разновозрастных и разнообразных по своей позиции и структурному стилю элементов геологических и тектонических структур горно-складчатых областей территории Восточной Сибири с сейсмической опасностью удалось установить некоторые закономерности в проявлении развития разрывных структур и сейсмичности территории. Исследования подобного рода известны в российской и англоязычной научной литературе как самостоятельные сейсмотектонические исследования, главной целью которых является «...установление или изучение связи проявлений сейсмичности и тектоники регионов...» [Geological Dictionary, 1973].

Другое, более развернутое, определение сейсмотектоники приводится американскими учеными, которые утверждают, что сейсмотектоника «является научной дисциплиной, изучающей взаимосвязь между землетрясениями, активной тектоникой и отдельными разломами региона. Стремится понять, какие данные несут ответственность за сейсмическую активность в конкретном районе путем анализа региональной тектоники, последних инструментально записанных сейсмических событий, исследования исторических и палеоземлетрясений, а также неотектонических и геоморфологических данных. Эта информация в дальнейшем может быть использована для количественной оценки сейсмической опасности того или иного региона. При проведении сейсмотектонического анализа территории требуется интеграция большого количества разнородных геолого-геофизических данных...» (по [Allen, 1975; Wallace, 1977; Yeats et al., 1997; McCalpin, 2009]).
Согласно практике проведения исследований подобного рода, сейсмические показатели используются для характеристики степени устойчивости геотектонического режима, определения зон контрастных тектонических движений, выявления доминирующих направлений подвижек. По глубине расположения очагов землетрясений, группирующихся в линии определенного простирания, судят о глубине заложения разрывов. Динамические параметры очагов дают сведения о величине и направлении сил, которые деформируют и разрушают горные породы. Результаты сейсмотектонических исследований выражаются обычно в виде сейсмотектонических карт, на которые наносятся данные о формах развития неотектонических структур и эпицентральные зоны землетрясений, что позволяет установить связь этих землетрясений с особенностями тектонического (неотектонического) строения местности и использовать эту связь для прогноза места, силы и частоты землетрясений, а также для составления карт сейсмического районирования [Gorshkov, 1984; Nikolaev et al., 1982; Imaev et al., 1990, 2000; Rogozhin, Platonova, 2002; Rogozhin, 2012].

Отсутствие единого подхода и четкой регламентирующей базы используемых геолого-геофизических характеристик среды часто не позволяет успешно провести такие сейсмотектонические исследования и ставит под сомнение результаты оценки уровня сейсмической опасности, полученные только методом инструментальных наблюдений и не подкрепленные определенными обязательными в настоящее время сейсмотектоническими исследованиями. В настоящей статье суммируется многолетний опыт проведения сейсмотектонических исследований в разнообразных сегментах сейсмоактивных структур территорий 
Якутии, Алтая, Саян, Тувы и области Байкальской рифтовой зоны, приводятся методические указания и обоснования целесообразности использования выбранных геолого-геофизических показателей для целей создания карты сейсмотектоники Восточной Сибири. Как и во всех остальных исследованиях подобного рода, эффективность и достоверность результатов сейсмотектонических исследований во многом обеспечиваются соблюдением стадийности наблюдений, которые проводятся в три этапа.

\section{2. СТАДИЙНОСТЬ ИССЛЕДОВАНИЙ}

На первом этапе проводится сбор исходного материала. Собственно исследования включают в себя совместный анализ всех имеющихся материалов по геологическому строению, сейсмическому режиму, неотектонике, истории развития рельефа, глубинному строению, напряженному состоянию и современным движениям земной коры. Также проводится дешифрирование материалов дистанционного зондирования Земли (ДЗ3). Иными словами, создается и анализируется материал, являющийся региональной сейсмотектонической базой данных.

Второй этап включает более конкретные исследования применительно к проектируемым народнохозяйственным объектам и связан с непосредственным полевым изучением активных разломов. Методика установления и изучения активных разломов основана на комплексе дистанционных и полевых методов, позволяющих по рельефу и составу молодых отложений выявить активные разломы, закартировать зоны связанных с ними деформаций и определить тип, амплитуду и среднюю скорость смещений. Следует особо подчеркнуть, что без реальных структурно-геологических и геоморфологических наблюдений непосредственно в полевых условиях все дальнейшие обобщения и построения будут неполноценными и недостоверными.

Третий этап (камеральный) подразумевает общую обработку результатов как полевых, так и фондовых и литературных материалов. Результаты обязательного тренчинга используются при этом не только для установления мест пересечения проектируемых объектов с активными разломами, но и для построения сейсмотектонической модели.

\section{З. ЗАДАЧИ И МЕТОДИКА СЕЙСМОТЕКТОНИЧЕСКИХ ИССЛЕДОВАНИЙ}

Основными элементами сейсмотектонической модели (карты зон возможных очагов землетрясе- ний (В03)) являются источники сейсмических воздействий - площадные (домены), характеризующие рассеянную (фоновую) сейсмичность, и линейные, отражающие сосредоточенную сейсмичность, т.е. потенциальные очаги сильных землетрясений (сейсмолинеаменты по [Ulomov, Shumilina, 1999]). Согласно сложившейся сейсмологической практике, в качестве линейных источников рассматриваются активные разломы. Для обьяснения доменной сейсмичности предложен новый критерий - геодинамически активные неотектонические зоны (ГАНЗ) [Gusev, Imaeva, 2014].

ГАНЗ, с позиции системного анализа, рассматривается как пространственно-локализованный целостный объект с многофакторным взаимодействием его основных компонентов в разрезе земной коры и верхней мантии (литосфере) - коровомантийный вариант; в разрезе литосферы и нижней мантии - суперглобальный вариант. Классификация ГАНЗ представляет собой систему, состоящую из десяти классов. Каждый из них характеризуется набором признаков: геодинамической обстановкой формирования геологических структур, скоростями горизонтального (по данным GPS и геологическим и геоморфологическим данным) и вертикального движения геологических тел (мм/год), размерами их пластических (пликативных) и разрывных деформаций, направлениями силовых тектонических полей, морфоструктурными типами эндогенного рельефа суши и морей, их высотами и значениями контрастности, геофизическими данными (величины теплового потока и поля силы тяжести), сейсмической томографии, глубинного строения (мощности земной коры, глубины залегания поверхности Мохоровичича и астеносферного слоя, мощности верхней и нижней мантии) [Gusev, Imaeva, 2014].

Примером построения карты ГАНЗ территории Восточной Сибири является рис. 1, на котором показано распределение зон с отдельной интенсивностью на исследуемой территории. Поскольку построение геолого-геофизических критериев сейсмичности производилось при помощи геоинформационных технологий, ставших доступными сравнительно недавно (ГИС-программы ArcView, ArcInfo), изображение отдельного информационного слоя не представляет большой проблемы, но позволяет лучше понять распространение отдельных частей слоя в пространстве.

Необходимость анализа новейшей позднекайнозойской (позднеплиоценовой-четвертичной) структуры изучаемой территории определялась тем, что новейшая тектоника представляет собой тот структурный каркас, в который вписываются активные разломы и другие проявления современной тектонической активности, напрямую 


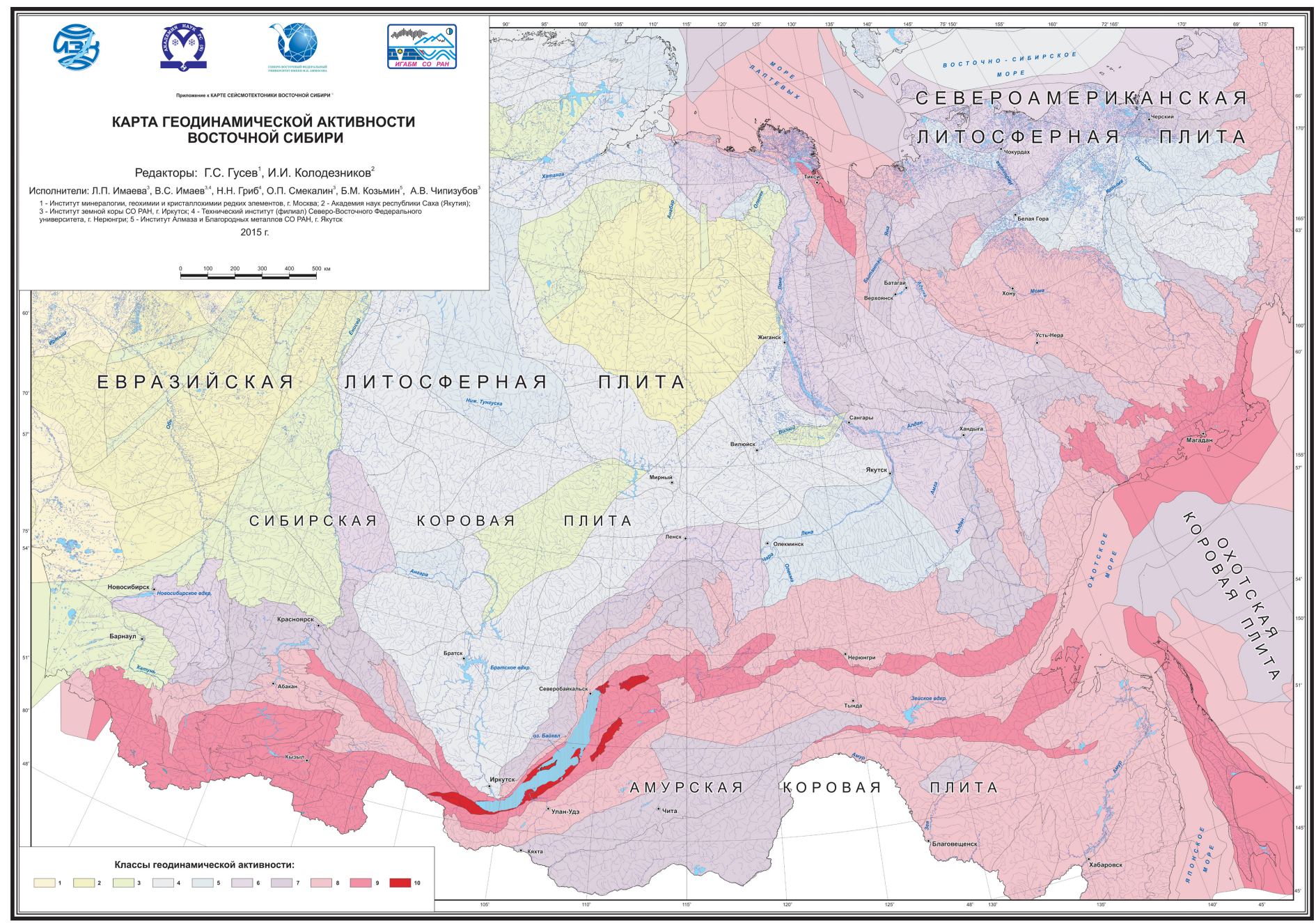

Рис. 1. Распределение геодинамически активных неотектонических зон (ГАНЗ) в пределах Восточной Сибири. Интенсивность окраски соответствует классу структур.

Fig. 1. Geodynamically active neotectonic zones (GANZ) in Eastern Siberia. The colour intensity range correlates with classes of structures.

связанные с региональной сейсмичностью. Плановое распределение элементов ГАНЗ в пределах Восточной Сибири показывает, что наиболее высокие показатели активности характерны для южной границы Сибирской платформы и ее северовосточного обрамления (Верхояно-Колымская складчатая область), хотя линейность простирания структур на востоке от платформы выражена не так четко, как вдоль южной границы. Вместе с тем, для всей территории к востоку от р. Лены характерны также весьма высокие значения ГАНЗ, впрочем некоторая линейность прослеживается и на о-ве Сахалин. Для центральных областей Сибирской платформы характерны невысокие, но в то же время и не нулевые значения активности. Разумеется, все это связано с разными режимами неотектонической жизни структур.

Следует отметить, что впервые интегральные оценки геодинамической активности тех или иных районов Азии были предложены в работах сибирских исследователей, успешно обьединивших их в геодинамическую активность литосферы Азии (ГАЛА) [Logatchev et al., 1987, 1991]. Такой же интегральный показатель (внерегиональный) использовался Г.И. Рейснером с коллегами в работах по установлению сейсмической опасности различных районов Евразии [Reisner et al., 1993].

Важнейшей составляющей сейсмотектонической модели являются прогнозные магнитуды землетрясений. Оценка максимально возможных магнитуд ожидаемых землетрясений производится по комплексу геолого-геофизических, сейсмологических и сейсмотектонических данных. Оценка магнитуды по комплексу сейсмотектонических данных основывается на глобальных статистических соотношениях между магнитудой землетря- 
сения, протяженностью разрыва и величиной подвижки по нему [Strom, 1993; McCalpin, 2011].

Конечным итогом сейсмотектонических исследований является создание сейсмотектонической модели региона и построение карты зон ВОЗ в крупных масштабах - 1:1000000, 1:500000 и $1: 200000$, что позволяет перейти к картам ДСР и в результате решить проблему определения уровня сейсмической опасности конкретных народнохозяйственных объектов. В ряде случаев такие исследования приводят к существенному сокращению участков с высокой (8-9 баллов) сейсмической опасностью по сравнению с картами общего сейсмического районирования (ОСР), что соответственно удешевляет будущее строительство. В других случаях могут быть найдены новые, ранее неизвестные источники сейсмических воздействий. Тогда уровень сейсмической опасности может быть повышен на локальных участках по сравнению с данными ОСР.

При проведении исследований очень важно соблюдение стадийности. Нарушение стадийности иногда может создать видимость сокращения сроков, но всегда отрицательно сказывается на результате. С учетом нестандартного характера исследований, а также особенностей их выполнения, работы по сейсмотектонике целесообразны только при непосредственном участии специализированных научных организаций, имеющих опыт в изучении активных разломов и высокую квалификацию исполнителей.

Сейсмотектоническое районирование предусматривает разделение территории на области, где ожидаемые местные землетрясения будут настолько слабы, что не окажут воздействия на население и систему его жизнеобеспечения, включая инженерные сооружения. Такие области считаются неспособными генерировать землетрясения и могут испытывать лишь сейсмические воздействия от удаленных сильных землетрясений. Другие области способны генерировать коровые землетрясения и потому называются зонами возникновения очагов землетрясений. Они подразделяются по их максимально возможной магнитуде и частоте возникновения. Выделение и параметризация, т.е. оценка сейсмического потенциала зон ВОЗ производятся путем комплексного применения двух равнозначных групп критериев: сейсмологической и геолого-геофизической.

Сейсмологическая группа включает в себя каталоги произошедших землетрясений: инструментальных, исторических и голоценовых палеособытий, выявляемых по геологическим и геоархеологическим данным, а также инструментальные и макросейсмические показатели распределения интенсивности сотрясений от ощутимых сейсмиче- ских событий, которые и служат основой всех дальнейших картографических построений. Кроме того, исследования планового распределения эпицентров землетрясений, помимо оценки самих сейсмических воздействий, позволяют очертить очаговые области сильных землетрясений и тем самым уточнить геометрию зон В03.

Приведенная карта планового распределения эпицентров землетрясений Восточной Сибири была построена при компиляции данных, полученных региональными отделениями геофизической службы РАН и СО РАН, а также с использованием каталогов местных землетрясений, которые доступны по литературным источникам и на интернет-ресурcax [Mackey et al., 2010; Ulomov, 2015].

Анализ планового распределения эпицентров землетрясений на территории исследований показывает приуроченность Южно-Сибирского сейсмического пояса к южной границе Сибирской платформы в области развития горно-складчатых орогенных структур Алтая, Саян, Тувы. Далее, пространственно тяготея к области Байкальской рифтовой зоны, проявления сейсмичности образуют эпицентральные поля Олекмо-Становой области и соединяются с сейсмичностью побережья Охотского моря. Другой, Арктико-Азиатский, сейсмический пояс прослеживается от побережья моря Лаптевых через систему структур Верхояно-Колымской горно-складчатой области на юго-восток, соединяясь с сейсмичностью побережья Охотского моря и п-ва Камчатка (рис. 2).

Другим немаловажным фактором проявления сильных землетрясений определенных районов служат механизмы очагов сильных землетрясений, сводный анализ которых позволяет установить напряженно-деформированное состояние среды в тех или иных элементах геологической и неотектонической структур. Фокальные механизмы очагов землетрясений, произошедших на территории Восточной Сибири, приводятся на рис. 3. Факты приводимых решений механизмов очагов землетрясений были скомпилированы из многочисленных работ разных авторов и интернет-ресурсов, находящихся в свободном доступе на соответствующих сайтах американской геологической службы [Mel'nikova, 2008; Radziminovich et al., 2012; Starovoit et al., 2003; Emanov et al., 2012; Koz'min, 1984; Imaeva et al., 2011, 2015; USGS Earthquake Hazards Program, 2015].

Одним из главных выводов, следующих из планового распределения эпицентров землетрясений и решений фокальных механизмов их очагов, является то, что вся наблюдаемая современная сейсмичность и древние палеоземлетрясения группируются в протяженные сейсмические пояса, пространственно тяготеющие к южной и восточ- 


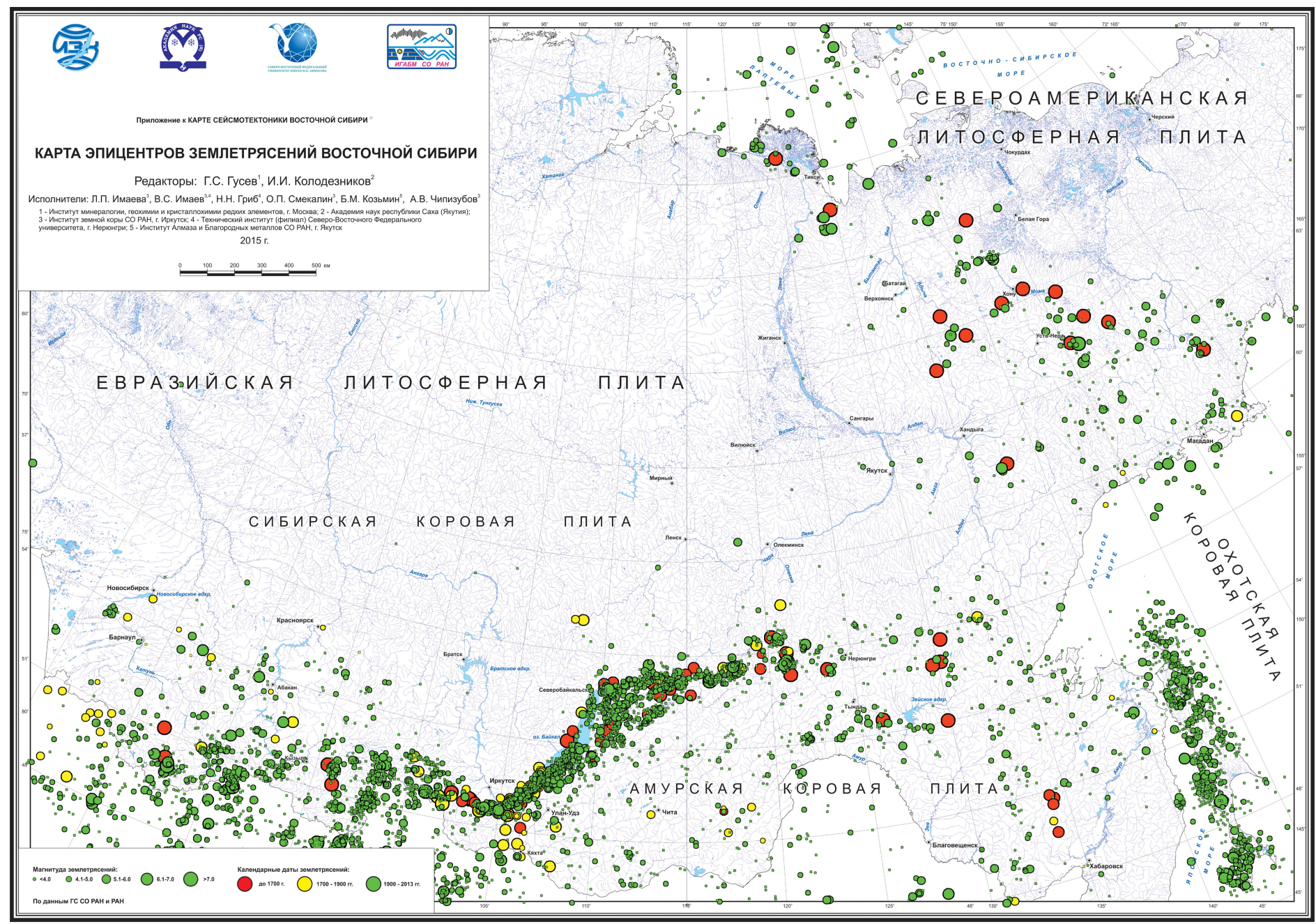

Рис. 2. Карта эпицентров Восточной Сибири (составлена по компиляционным данным геофизической службы РАН и СО РАН, а также литературным данным и из интернет-ресурсов [Mackey et al., 2010; Ulomov, 2015].

Fig. 2. Earthquake epicentres in Eastern Siberia. The map is based on data consolidated by RAS Geophysical Survey and Siberian Branch of RAS, published records and data available in the internet resources [Mackey et al., 2010; Ulomov, 2015].

ной границе Евразийской литосферной плиты. А тип напряженно-деформированного состояния земной коры указывает на превалирование процессов горизонтального сжатия вдоль всей континентальной части этой границы (за исключением Байкальской рифтовой области) и фрагментирование по геодинамическому принципу на отдельные сегменты Южно-Сибирского и Арктико-Азиатского сейсмических поясов.

Применение геолого-геофизической группы критериев зон ВОЗ в настоящее время состоит в выделении и параметризации активных геологических структур, в которых землетрясения определенной магнитуды и частоты возникали в недавнем прошлом и могут ожидаться в близком будущем, к которому относятся оценки сейсмической опасности. Материалы детального изучения активных разломов и вторичных эффектов древних землетрясений, наряду с другими сейсмотектоническими и сейсмологическими данными, ложатся в основу карты зон возможных очагов землетрясений, что представляется едва ли не главной целью сейсмотектонических исследований [Trifonov et al., 1993, 1997; Rogozhin, 2012; Imaev et al., 2000; Yeats et al., 1997]. Поскольку активные разломы, как правило, соответствуют главным зонам ВОЗ региона, даже качественный анализ рисунка и параметров разломов позволяет оконтурить такие зоны и выполнить их предварительное ранжирование. Численные характеристики зон В03, среди которых определяющими являются максимальная ожидаемая магнитуда землетрясений $\left(\mathrm{M}_{\max }\right)$ и период повторяемости таких землетрясений, в основном опираются на сейсмологические данные.

Детальное изучение активных разломов дает возможность составить представление о структуре 


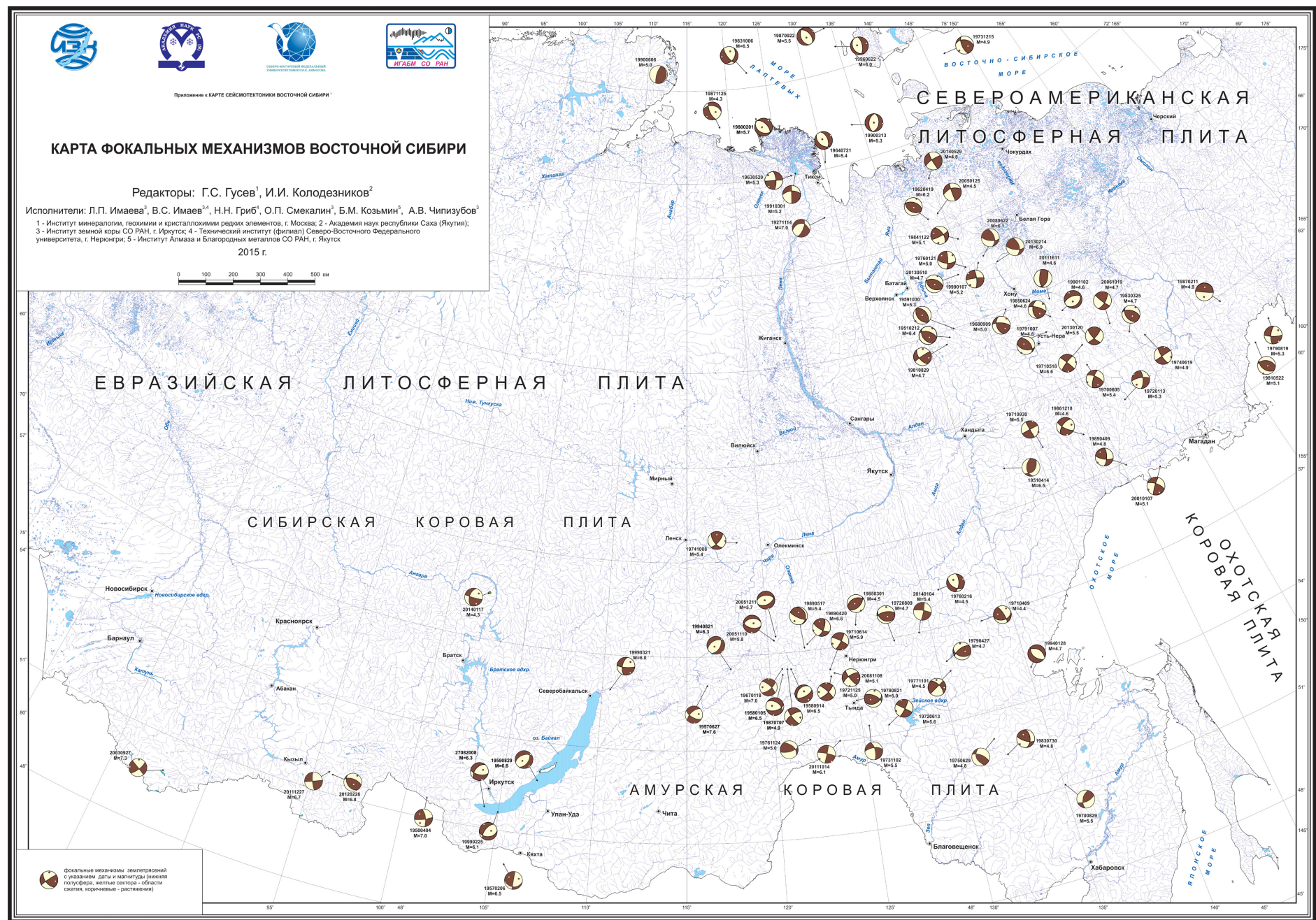

Рис. 3. Карта фокальных механизмов очагов землетрясений Восточной Сибири [Centroid Moment Tensor Catalog, 2015].

Fig. 3. Earthquake focal mechanisms map of Eastern Siberia [Centroid Moment Tensor Catalog, 2015].

очага и древних, доисторических, сейсмических событиях, произошедших в этих же очаговых зонах. Очаги сильных и сильнейших землетрясений представляют собой устойчивые структуры в геологической среде (активные разломы), положение которых определено особым сочетанием геологогеофизических условий, причем кинематика подвижки от раза к разу может изменяться.

В большинстве случаев выходы очагов сильных современных землетрясений на поверхность образуют некую область - зону сейсморазрывов. Ширина ее может достигать нескольких сотен метров и даже первых километров, в зависимости от конкретных геолого-геоморфологических условий и силы землетрясения. При этом разрывы могут появляться на поверхности на разных участках зоны разлома, т.е. менять свое положение от одного землетрясения к другому. Суммарное смещение в очаге в приповерхностных условиях может рассеиваться в виде множества разрывов и связных де- формаций, однако все они образуют характерные структурные рисунки, свойственные тектоническим деформациям в целом. Обычно они приурочены к определенным геологическим структурам и формам рельефа, сформированным предыдущими сейсмическими подвижками. Эти древние события находят отражение не только в смещениях молодых отложений и форм рельефа, но и в развитии древних вторичных нарушений (палеосейсмодислокаций).

Палеосейсмологические исследования решают две основные задачи, имеющие важное практическое и теоретическое значение. Одна из них, направленная на установление величины самих палеособытий, касается выделения одноактных и приблизительно одновозрастных палеосейсмодислокаций (ПСД). Вторая связана с определением морфокинематических типов активных разломов, по которым происходили эти разрывообразующие палеоземлетрясения [Arzhannikov, 2000; Solonenko, 


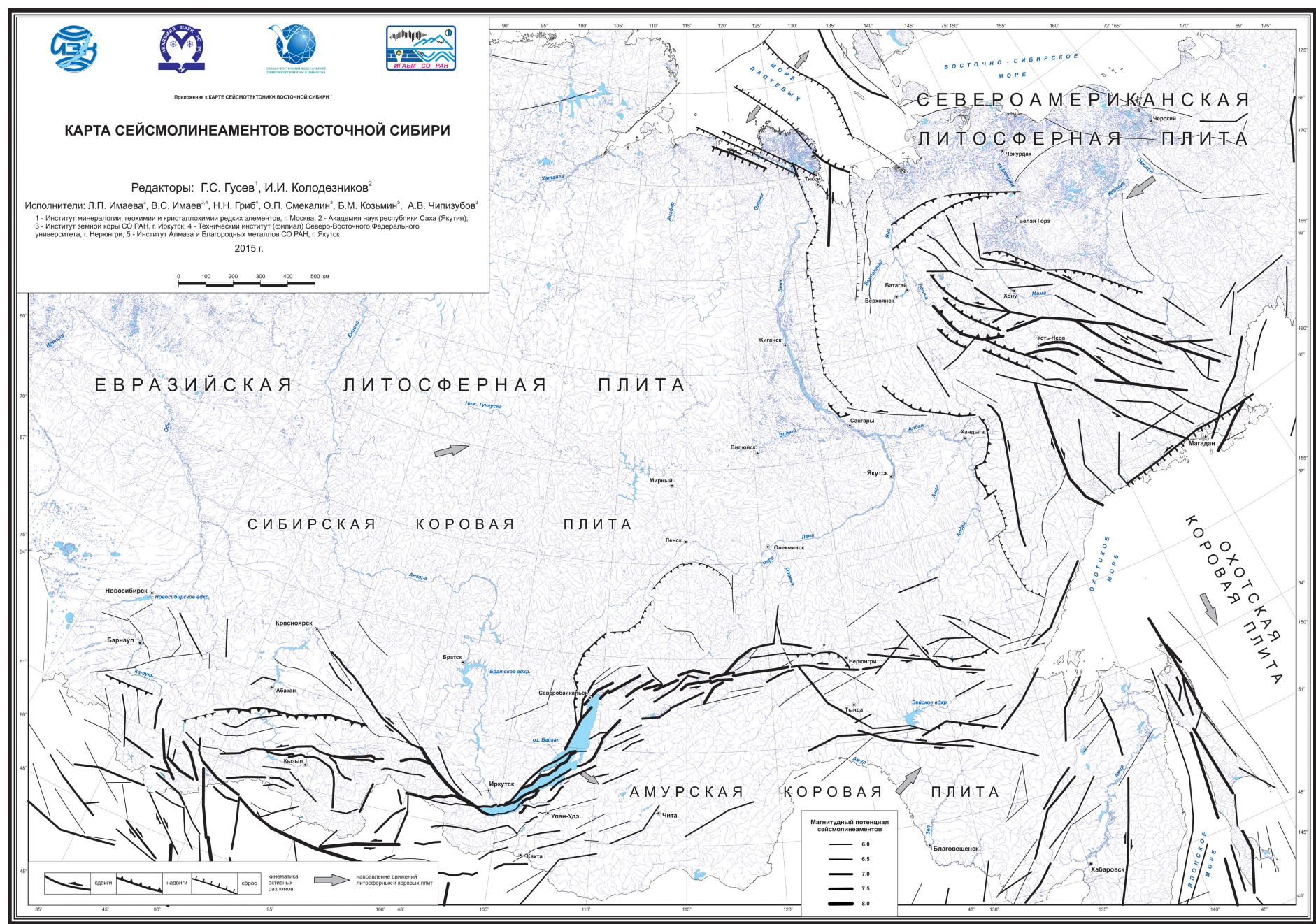

Рис. 4. Карта сейсмолинеаментов Восточной Сибири с предполагаемой магнитудой возможных землетрясений и установленной кинематикой смещения по ним.

Fig. 4. Seismic lineaments map of Eastern Siberia. It shows potential earthquake magnitudes and the kinematics of shearing.

1977; Smekalin et al., 2011; Strom, Nikonov, 1997; Rogozhin, Platonova, 2002]. В результате проведенных многолетних исследований все установленные активные разломы были вынесены нами на соответствующую топографическую основу территории Восточной Сибири с установленной магнитудой генерируемых ими землетрясений (рис. 4).

Обращает на себя внимание распространение активных разломов вдоль южной границы Евразийской литосферной плиты, в области взаимодействия ее с Амурской (Китайской) плитой, и формирование пояса активных разломов вдоль восточной границы Евразийской плиты, в пределах ВерхояноКолымской складчатой системы, которая формирует западную границу Североамериканской литосферной плиты. Для планового распределения разломов характерно наличие крупных сейсмолинеаментов, способных генерировать самые сильные землетрясения с магнитудой $\mathrm{M}=7.5-8.0$, развитых в осевых частях выделенных сейсмических поясов и тяготеющих к самым активным частям геодинамически активных неотектонических зон.

\section{4. КАРТА СЕЙСМОТЕКТОНИКИ И ДИНАМИКА ФОРМИРОВАНИЯ СЕЙСМОГЕНЕРИРУЮЩИХ СТРУКТУР ВОСТОЧНОЙ СИБИРИ}

Комплексный анализ геолого-геофизических, геоморфологических и неотектонических данных, систем позднекайнозойских активных разломов, сейсмичности, результатов тектонофизических исследований позволил выявить на юге Восточной Сибири протяженный сейсмический пояс - ЮжноСибирский, состоящий из нескольких крупных отдельных сегментов: Алтай-Саяно-Тувинского, Байкальской рифтовой области и Олекмо-Становой зоны, соединяющих собой проявления сейсмич- 


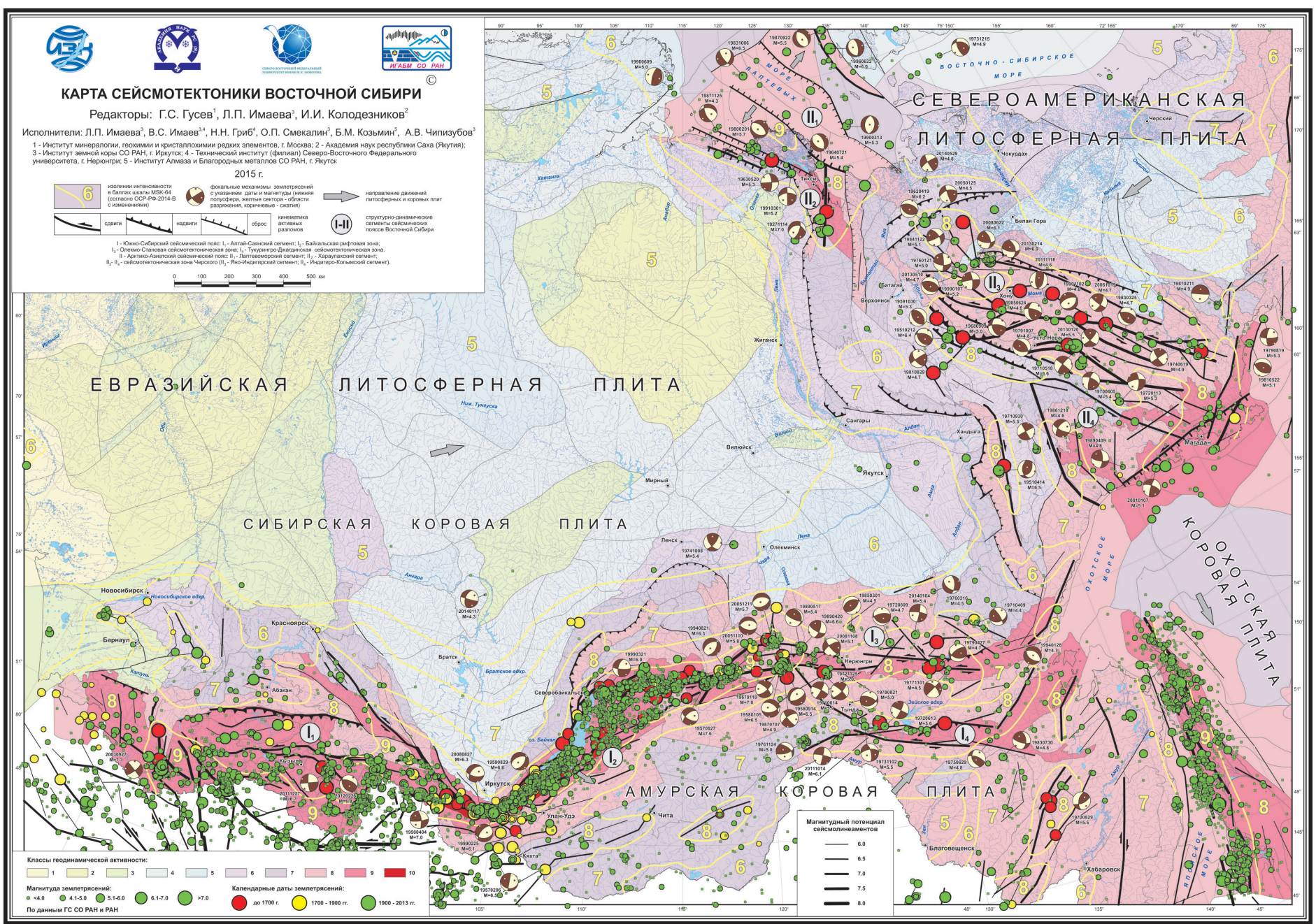

Рис. 5. Карта сейсмотектоники Восточной Сибири с нанесенными на нее изолиниями балльности возможных интенсивностей сейсмических сотрясений (по шкале MSK-64), соответствующих карте ОСР-2014-В (с повторяемостью 1000 лет), с добавлениями и исправлениями.

Fig. 5. Seismotectonic map of Eastern Siberia. Isolines show potential intensity of seismic events (MSK-64 scale), which correspond to OSR-2014-V Map (repeatability period of 1000 years) with additions and amendments.

ности сдвиговых структур Алтая, Саянской и Тувинской горно-складчатых областей, растяжения Байкальской рифтовой зоны, транспрессионные сдвигово-надвиговые перемещения Олекмо-Становой зоны и сейсмичность Охотского моря. Другой крупный сейсмический пояс - Арктико-Азиатский - прослеживается вдоль границы между Евразийской и Североамериканской литосферными плитами и соединяет сейсмичность побережья Арктического океана, связанную с растяжением земной коры, далее через сдвигово-надвиговые структуры, развитые на континентальном отрезке границы плит, соединяется с сейсмогенными структурами побережья Охотского моря и п-ова Камчатка.

Обобщенные материалы по сейсмотектонике и новейшей геодинамике сейсмических поясов на северо-востоке Азии дают возможность весьма успешно вести прогноз сценариев поведения сейсмической активности территории, с определением места и предельной величины возможной сейсмической катастрофы. Определение структурной позиции позволяет предполагать наиболее опасные направления выделения сейсмической энергии и снижать степень риска расположения потенциальных народнохозяйственных объектов. Построенная карта сейсмотектоники Восточной Сибири представляет собой комплексную многослойную модель развития сейсмотектонических процессов, протекающих на исследуемой территории. Карта для этой территории впервые составлена с использованием геоинформационных технологий. Применение новых технологий позволило при построении оперировать целостной картой, 
как совокупностью нескольких информационных слоев, содержащих определенную заданную информацию, характеризующую сейсмотектонические процессы территории Восточной Сибири (рис. 5).

Дополнительно на карту была вынесена интенсивность возможных сейсмических сотрясений в баллах (по шкале MSK-64), согласно новой карте Общего сейсмического районирования РФ (ОСР2014-В), соответствующая расчетным событиям с периодичностью 1 в 1000 лет. Именно такой диапазон будущих толчков соответствует интересам народнохозяйственного освоения территории. Вместе с тем следует учесть, что рассматриваемая территория (особенно территория Якутии) все еще представляет собой весьма сложный и малоосвоенный (недостаточно изученный) регион России, где происходят активные деформации между несколькими тектоническими плитами, что, конечно, требует дальнейшего детального изучения отдельных частей этих сейсмических поясов. Это, прежде всего, относится к прибрежно-шельфовым областям арктических морей Восточной Сибири, с активным освоением которых связана ближайшая стратегия развития РФ и, в конечном итоге, экономическая и социальная безопасность нашей страны.

\section{5. ЗАКЛЮЧЕНИЕ}

Подводя итог сейсмотектоническим исследованиям, можно констатировать:

1. Карта сейсмотектоники Восточной Сибири является первым наглядным примером построения карты нового поколения (электронная база данных сейсмотектонических параметров), которая объединяет элементы геолого-геофизических параметров и сейсмичности и объясняет особенности современной геодинамики (а соответственно и сейсмическую опасность) региона.

2. Построение таких карт позволяет перейти к созданию карт детального сейсмического районирования отдельных частей активно промышленно осваиваемых районов Восточной Сибири и обоснованно установить уровень сейсмической угрозы тех или иных районов проживания коренного населения Сибири. Данный подход позволит приступить к новому этапу исследований проблемы сейсмобезопасности, а созданные региональные сейсмогеодинамические модели будут способствовать уточнению исходного сейсмического балла существующих нормативных карт общего и детального сейсмического районирования.

3. Карта должна использоваться органами исполнительной власти отдельных районов, комитетами по чрезвычайным ситуациям с целью владения информацией о возможном негативном влиянии сильных местных землетрясений, определения балла сейсмической угрозы конкретных населенных пунктов.

\section{6. БЛАГОДАРНОСТИ}

Данное научное исследование выполнено при поддержке интеграционного проекта СО РАН и гранта Министерства науки и образования РФ (Гос. задание № 5.1771.2014/К), а также гранта РНФ № 15-17-20000 (работы, выполненные в рамках анализа арктической территории РФ). Особую благодарность хотелось бы выразить д.г.-м.н. С.И. Шерману, д.г.-м.н. Г.С. Гусеву (ИМГРЭ, г. Москва) и д.г.-м.н И.И. Колодезникову (АН РС(Я), г. Якутск) за постоянное внимание и поддержку этих непривычных пока еще для большого круга сейсмологов исследований.

\section{7. ЛИТЕРАTУРA / REFERENCES}

Allen C.R., 1975. Geological criteria for evaluating seismicity. Geological Society of America Bulletin 86 (8), $1041-1057$. http://dx.doi.org/10.1130/0016-7606(1975)86<1041:GCFES>2.0.CO;2.

Arzhannikov S.G., 2000. Paleoseismodislocations in the Ottugtaiginsk-Azassky fault zone (Eastern Tuva). Geologiya $i$ Geofizika (Russian Geology and Geophysics) 41 (11), 1499-1504.

Centroid Moment Tensor Catalog, 2015. Available from: http://www.globalcmt.org/CMTsearch.html (last accessed 08.09.2015)

Emanov A.F., Emanov A.A., Leskova E.V., Seleznev V.S., Filina A.G., 2012. Earthquake in Tuva (27.12.2011, ML=6.7) and aftershocks. Vestnik Otdelenia nauk о Zemle RAN 4, NZ2002 (in Russian) [Еманов А.Ф., Еманов А.А., Лескова Е.В., Селезнев В.C., Филина Е.Г. Тувинское землетрясение 27.12.2011 г. ML=6.7 и его афтершоки // Вестник ОНЗ PAH. 2012. T. 4. NZ2002]. http://dx.doi.org/10.2205/2012NZ000112.

Geological Dictionary, 1973. Two volumes. Nedra, Moscow, 986 p. (in Russian) [Геологический словарь. В двух томах. М.: Недра, 1973. 986 с.].

Gorshkov G.P., 1984. Regional Seismotectonics of the Southern Territory of the USSR. Alpine Belt. Nauka, Moscow, 272 p. (in Russian) [Горшков Г.П. Региональная сейсмотектоника территории юга СССР. Альпийский пояс. М.: Наука, 1984. 272 с.]. 
Gusev G.S., Imaeva L.P., 2014. Recent and current tectonic (geodynamic) activity of the territory of Russia. Razvedka $i$ Okhrana Nedr (Subsoil Prospecting and Protection) (12), 23-29 (in Russian) [Гусев Г.С., Имаева Л.П. Новейшая и современная тектоническая (геодинамическая) активность территории России // Разведка и охрана недр. 2014. № 12. C. 23-29].

Imaev V.S., Imaeva L.P., Koz'min B.M., 1990. Active Faults and Seismotectonics of North-Eastern Yakutia. Yakutia Scientific Centre, Siberian Branch of the USSR Acad. Sci., Yakutsk, 138 p. (in Russian) [Имаев В.С., Имаева Л.П., Козьмин Б.М. Активные разломы и сейсмотектоника Северо-Восточной Якутии. Якутск: ЯНЦ СО АН СССР, 1990. 138 c.].

Imaev V.S., Imaeva L.P., Koz'min B.M., 2000. Seismotectonics of Yakutia. GEOS, Moscow, 227 p. (in Russian) [Имаев B.C., Имаева Л.П., Козьмин Б.М. Сейсмотектоника Якутии. М.: ГЕОС, 2000. 227 с.].

Imaeva L.P., Imaev V.S., Koz'min B.M., 2011. Seismotectonic analysis of the Yana-Indigirka segment of the Chersky zone. Izvestiya, Physics of the Solid Earth 47 (12), 1045-1057. http://dx.doi.org/10.1134/S1069351311120056.

Imaeva L.P., Koz'min B.M., Imaev V.S., Mackey K.G., 2015. Structural dynamic analysis of the epicentral zone of the IlinTas earthquake (Feb 14, 2013, Ms=6.9). Journal of Seismology 19 (2), 341-353. http://dx.doi.org/10.1007/ s10950-014-9469-5.

Koz'min B.M., 1984. Seismic Belts of Yakutia and Earthquake Focal Mechanisms. Nauka, Moscow, 125 p. (in Russian) [Козьмин Б.М. Сейсмические пояса Якутии и механизмы очагов их землетрясений. М.: Наука, 1984. 125 с.].

Logatchev N.A., Sherman S.I., Levi K.G., 1987. Geodynamic activity of the lithosphere in Siberia in the Cenozoic. Geologiya i Geofizika (Russian Geology and Geophysics) (8), 3-10 (in Russian) [Логачев Н.А., Шерман С.И., Леви К.Г. Геодинамическая активность литосферы Сибири в кайнозое // Геология и геофизика. 1987. № 8. С. 3-10].

Logatchev N.A., Sherman S.I., Levi K.G., 1991. Geodynamic activity of the lithosphere in Asia: bases for analysis and principles of mapping. In: Geodynamics and Development of Tectonosphere. Proceedings of ITC Tectonic Meeting. Nauka, Moscow, p. 31-39 (in Russian) [Логачев Н.А., Шерман С.И., Леви К.Г. Геодинамическая активность литосферы Азии: основы анализа и принципы картирования // Геодинамика и развитие тектоносферы: Труды Тектонического совещания МТК. М.: Наука, 1991. С. 31-39].

Mackey K.G., Fujita K., Hartse H.E., Stead R.J., Steck L.K., Gunbina L.V., Leyshuk N., Shibaev S.V., Koz'min B.M., Imaev V.S., Gordeev E.I., Chebrov V.N., Masal'ski O.K., Gileva N.A., Bormatov V.A., Voitenok A.A., Levin Y.N., Fokina T.A., 2010. Seismicity Map of Eastern Russia, 1960-2010. Seismological Research Letters 81 (5), 761-768. http://dx.doi.org/ 10.1785/gssrl.81.5.761.

McCalpin J.P. (Ed.), 2009. Paleoseismology. Second Edition. Academic Press, Amsterdam-London, 615 p.

McCalpin J.P. (Ed.), 2011. Paleoseismology. Two volumes. Nauchny Mir, Moscow, 878 p. (in Russian) [Палеосейсмология. В 2-х томах / Ред. Дж.П. МакКалпин. М.: Научный мир, 2011. 878 с.].

Mel'nikova V.I., 2008. Crustal Deformation Parameters of the Baikal Rift Zone from Seismological Data. Synopsis of the Ph.D. Thesis. Institute of the Earth's crust, Irkutsk, 38 p. (in Russian) [Мельникова В.И. Деформационные параметры земной коры Байкальской рифтовой зоны по сейсмологическим данным: Автореф. дис. ... докт. геол.-мин. наук. Иркутск: ИЗК СО РАН, 2008. 38 с.].

Nikolaev V.V., Semenov R.F., Semenova V.G., Solonenko V.P., 1982. Seismotectonics, Volcanoes and Seismic Zonation of the Stanovoy Ridge. Nauka, Novosibirsk, 150 p. (in Russian] [Николаев В.В., Семенов Р.Ф., Семенова В.Г., Солоненко В.П. Сейсмотектоника, вулканы и сейсмическое районирование хребта Станового. Новосибирск: Наука, 1982.150 с.].

Radziminovich Ya.B., Mel'nikova V.I., Seredkina A.I., Gileva A.I., Radziminovich N.A., Papkova A.A., 2012. The Balei earthquake of 6 January 2006 (Mw=4.5): a rare case of seismic activity in eastern Transbaikalia. Russian Geology and Geophysics 53 (10), 1100-1110. http://dx.doi.org/doi:10.1016/j.rgg.2012.08.010.

Reisner G.I., Ioganson L.I., Reisner M.G., Baranov Yu.E., 1993. Typification of the Earth's Crust and Recent Geological Processes. UIFE RAS, Moscow, 208 p. (in Russian) [Рейснер Г.И., Иогансон Л.И., Рейснер М.Г., Баранов Ю.Е. Типизация земной коры и современные геологические процессы. М.: ОИФЗ РАН, 1993. 208 с.].

Rogozhin E.A., 2012. Features of Regional Seismotectonics. IPE RAS, Moscow, 340 p. (in Russian] [Рогожин E.A. Очерки региональной сейсмотектоники. М.: ИФЗ РАН, 2012. 340 с.].

Rogozhin E.A., Platonova S.G., 2002. Focal Zones of Strong Earthquakes in Mountainous Altai in the Holocene. UIFE RAS, Moscow, 130 p. (in Russian) [Рогожин Е.А., Платонова С.Г. Очаговые зоны сильных землетрясений Горного Алтая в голоцене. М.: ОИФЗ РАН, 2002. 130 с.].

Smekalin O.P., Imaev V.S., Chipizubov A.V., 2011. Paleoseismology of Eastern Siberia (Applied Practice). IEC SB RAS, Irkutsk, 99 p. (in Russian) [Смекалин О.П., Имаев В.С., Чипизубов А.В. Палеосейсмология Восточной Сибири (некоторый опыт практического применения). Иркутск: ИЗК СО РАН, 2011. 99 с.].

Solonenko V.P. (Ed.), 1977. Seismic zoning of Eastern Siberia and its geological and geophysical base. Nauka, Novosibirsk, 301 p. (in Russian) [Сейсмическое районирование Восточной Сибири и его геолого-геофизические основы / Ред. В.П. Солоненко. Новосибирск: Наука, 1977. 301 с.]

Starovoit O.E., Chepkunas L.S., Gabsatarova I.P., 2003. Parameters of 27 September 2003 earthquake in Altai according to instrumental data. Vestnik Otdelenia nauk o Zemle RAN 1 (21), 1-12 (in Russian) [Старовойт O.E., Чепкунас Л.С., Габсатарова И.П. Параметры землетрясения 27 сентября 2003 года на Алтае по инструментальным данным // Вестник Отделения наук о Земле. 2003. № 1 (21). С. 1-12]. 
Strom A.L., 1993. Comparison of parameters of recent and paleoseismotectionic structures. Fizika Zemli (9), 38-42 (in Russian] [Стром А.Л. Сопоставление параметров современных и палеосейсмотектонических дислокаций // Физика Земли. 1993. № 9. С. 38-42].

Strom A.L., Nikonov A.A., 1997. Relations between the seismogenic fault parameters and earthquake magnitude. Izvestiya, Physics of the Solid Earth 33 (12), 1011-1022.

Trifonov V.G., Kozhurin A.I., Lukina N.V., 1993. Studies and mapping of active faults. In: Seismicity and seismic zonation of North Eurasia. Vol. 1. UIFE RAS, Moscow, p. 196-206 (in Russian) [Трифонов В.Г., Кожурин А.И., Лукина Н.В. Изучение и картирование активных разломов // Сейсмичность и сейсмическое районирование Северной Евразии. М.: ОИФЗ РАН, 1993. Т. 1. С. 196-206].

Trifonov V.G., Vostrikov G.A., Trifonov R.V., Soboleva O.V., 1997. Active faults in Eurasia: geodynamic aspect. In: Tectonic and geodynamic phenomena. Nauka, Moscow, p. 174-195 (in Russian) [Трифонов В.Г., Востриков Г.А., Трифонов P.B., Соболева О.В. Активные разломы Евразии: геодинамический аспект // Тектонические и геодинамические феномены. М.: Наука, 1997. С. 174-195].

Ulomov V.I., 2015. Attention! Earthquake! (in Russian) [Уломов В.И. Внимание! Землетрясение!]. Available from: http://seismos-u.ifz.ru/ (last accessed 14.08.2015).

Ulomov V.I., Shumilina L.S., 1999. The Set of General Seismic Zonation Maps of the Territory of the Russian Federation - OSR-97. Scale 1:8000000. Explanatory Note. UIFE RAS, Moscow, 57 p. (in Russian) [Уломов В.И., Шумилина Л.C. Комплект карт общего сейсмического районирования территории Российской Федерации - OCР-97. Масштаб 1:8000000. Объяснительная записка. М.: ОИФЗ РАН, 1999. 57 с.].

USGS Earthquake Hazards Program, 2015. Available from: http://earthquake.usgs.gov/earthquakes/ (last accessed 14.08.2015).

Wallace R.E., 1977. Profiles and ages of young fault scarps, north-central Nevada. Geological Society of America Bulletin 88 (9), 1267-1281. http://dx.doi.org/10.1130/0016-7606(1977)88<1267:PAAOYF>2.0.CO;2.

Yeats R.S., Sieh K., Allen C.R., 1997. The Geology of Earthquakes. Oxford University Press, New York, 568 p.

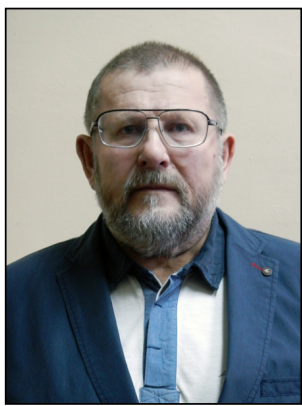

Имаев Валерий Сулейманович, докт. геол.-мин. наук, г.н.с.

Институт земной коры СО РАН

664033, Иркутск, ул. Лермонтова, 128, Россия

e-mail: imaev@crust.irk.ru

Imaev, Valery S., Doctor of Geology and Mineralogy, Chief Researcher

Institute of the Earth's Crust, Siberian Branch of RAS

128 Lermontov street, Irkutsk 664033, Russia

\e-mail:imaev@crust.irk.ru

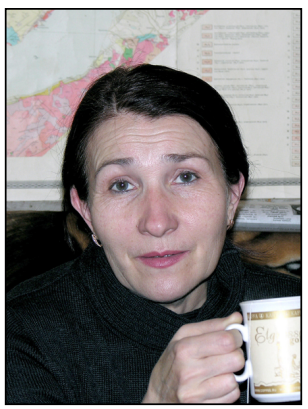

Имаева Людмила Петровна, канд. геол.-мин. наук, с.н.с

Институт земной коры СО РАН

664033, Иркутск, ул. Лермонтова, 128, Россия

e-mail: imaeva@crust.irk.ru

Imaeva, Lyudmila P., Candidate of Geology and Mineralogy, Senior Researcher

Institute of the Earth's Crust, Siberian Branch of RAS

128 Lermontov street, Irkutsk 664033, Russia

e-mail: imaeva@crust.irk.ru

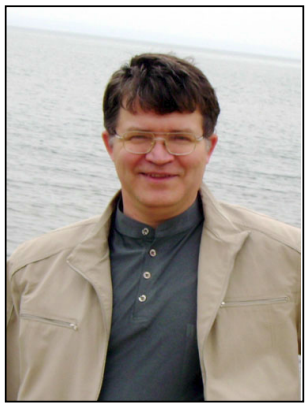

Смекалин Олег Петрович, канд. геол.-мин. наук, с.н.с.

Институт земной коры СО РАН

664033, Иркутск, ул. Лермонтова, 128, Россия

e-mail: smekalin@crust.irk.ru

Smekalin, Oleg P., Candidate of Geology and Mineralogy, Senior Researcher

Institute of the Earth's Crust, Siberian Branch of RAS

128 Lermontov street, Irkutsk 664033, Russia

e-mail: smekalin@crust.irk.ru 


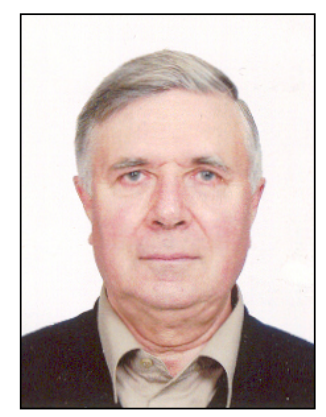

Козьмин Борис Михайлович, канд. геол.-мин. наук, в.н.с. Институт геологии алмаза и благородных металлов СО РАН 677007, Республика Саха (Якутия), Якутск, пр. Ленина, 39, Россия e-mail: b.m.kozmin@diamond.ysn.ru

Koz'min, Boris M., Candidate of Geology and Mineralogy, Leading Researcher Institute of Diamond and Precious Metals Geology, Siberian Branch of RAS 39 Lenin avenue, Sakha (Yakutia) Republic, Yakutsk 677007, Russia e-mail: b.m.kozmin@diamond.ysn.ru

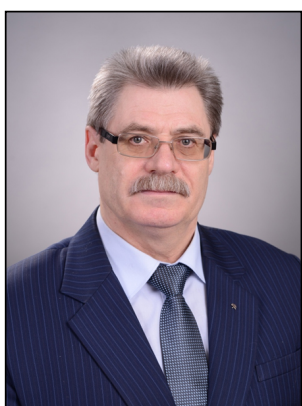

Гриб Николай Николаевич, докт. техн. наук, профессор, заместитель директора

Технический институт (филиал) Северо-Восточного федерального университета им. М.К. Аммосова 678960, Республика Саха (Якутия), Нерюнгри, ул. Кравченко, 16, Россия

e-mail: grib@nfygu.ru

Grib, Nikolai N., Doctor of Technical Sciences, Professor, Deputy Director Technical Institute (branch) of M.K. Ammosov North-Eastern Federal University 16 Kravchenko street, Sakha (Yakutia) Republic, Neryungri 678960, Russia

e-mail: grib@nfygu.ru

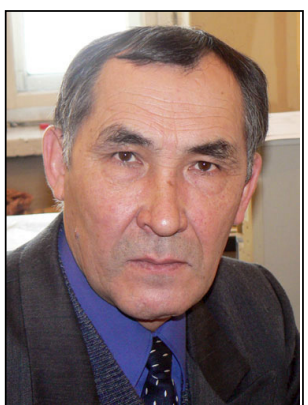

Чипизубов Анатолий Васильевич, докт. геол.-мин. наук, с.н.с.

Институт земной коры СО РАН

664033, Иркутск, ул. Лермонтова, 128, Россия

e-mail: chipizub@crust.irk.ru

Chipizubov, Anatoly V., Doctor of Geology and Mineralogy, Senior Researcher Institute of the Earth's Crust, Siberian Branch of RAS

128 Lermontov street, Irkutsk 664033, Russia

e-mail: chipizub@crust.irk.ru 